\title{
Water quality characteristics and pollution levels of heavy metals in Lake Haiq, Ethiopia
}

\author{
Aregawi Teklay ${ }^{1}$ and Meareg Amare ${ }^{1 *}$
}

${ }^{1}$ Department of Chemistry, Bahir Dar University, P.O. Box 79, Bahir Dar, Ethiopia

\begin{abstract}
The main aim of this study was to assess the level of water quality of Lake Haiq, Ethiopia with respect to selected physical parameters and heavy metals. Parameters such as temperature, $\mathrm{pH}$, turbidity, electrical conductivity and total dissolved solids were measured in situ. While total alkalinity, chloride, ammonia, nitrate and sulphate were investigated using standard analytical procedures. the level of the studied heavy metals $(\mathrm{Pb}, \mathrm{Cd}, \mathrm{Cu}$ and $\mathrm{Zn})$ was determined using the inductively coupled plasma-optical emission spectrometry. Sulphate, nitrate, ammonia, chloride, and total dissolved solids were within the recommended levels for a drinking water by the WHO guidelines. In contrast, the total alkalinity, turbidity and $\mathrm{pH}$ values were above the recommended limits, indicating the inconveniency to use the water for drinking. While $\mathrm{Cd}$ in the water sample was under the method detection limit $(<0.0039 \mathrm{mg} / \mathrm{L})$, the levels of $\mathrm{Cu}$, and $\mathrm{Zn}$ were found to be under the respective permitted limits. However, the level of lead throughout the sampling sites ranged from 0.064 to 0.108 , which is 6 to 10 times higher than the permitted level in drinking water confirming the awkwardness of using the lake water for drinking. A detailed study of the catchment on the possible sources of pollution is recommended so that appropriate control measures could be taken by the governmental bodies.
\end{abstract}

Key words/phrases: Heavy metals, Lake Haiq, South Wollo, Water pollution

DOI: http://dx.doi.org/10.4314/ejst.v8i1.2

\section{INTRODUCTION}

Water is an essential component for survival of life on earth, which contains minerals, important for humans as well as for earth and aquatic life (Arian et al., 2008). Freshwater accounts $3 \%$ of the total water on the earth of which only a small percentage $(0.01 \%)$ is available for human use (Arumugam et al., 2013). Even this small portion of freshwater is under immense stress. Rapid population growth, urbanization, industrialization, use of fertilizers in the agriculture and other human activities are some of the causes for the pollution of the freshwater with different contaminants (Arian et al., 2008; Pati et al., 2012; Arumugam et al., 2013).

Water pollution is the degradation of the quality of water rendering its suitability for its intended purpose. Water pollutants can be broadly classified as organic, inorganic, suspended solids and sediments, heavy metals, radioactive materials and heat (Zenebe Yirgu, 2011). Heavy metals are among the most harmful water pollutants due to their non-biodegradability, long biological half-life and their potential to accumulate in aquatic ecosystems (Arian et al., 2008; Moore et al., 2009; Benzer et al., 2013). Though aquatic pollution due to heavy metals is less visible in contrast to others, its effects on the ecosystem and humans can be intensive and very extensive (Arian et al., 2008; Zenebe Yirgu, 2011).

Toxicity level of heavy metals depends on the type of metal, its biological role, and the type of organisms that are exposed to it. The heavy metals linked most often to human poisoning are lead, mercury, arsenic and cadmium. Others, including copper, zinc, and trivalent chromium are actually required by the body in

\footnotetext{
*Corresponding author: amaremeareg@yahoo.com
}

(C) This is an Open Access article distributed under the terms of the Creative Commons Attribution License (http://creativecommons.org/licenses/CC BY4.0) 
small amounts and hence are essential, but can also be toxic in larger doses (Tolera Seda, 2007; Verma and Dwivedi, 2013). The presence of these metals in the aquatic ecosystem while has far-reaching consequences on the biota and man; their toxic effects on man are known to cause damaged or reduced mental and central nervous function. Abnormal blood composition, and damaged lungs, kidneys, liver, and other vital human organs are also known to be among the consequences of heavy metal toxicity (WHO,1984; Igbinosa et al., 2012).

This study focuses on Lake Haiq, which is one of the fresh and closed highland lakes of Ethiopia used by the local inhabitants for different purposes including fishing, recreation, irrigation and drinking. Human activities such as agricultural practice, deforestation, discharging of domestic sewage, and waste disposal from the town around it (Haiq) including a garage near the lake may cause the deterioration of the quality of the water system of Lake Haiq. Moreover, since the lake is located at a short distance from the main road of Addis Ababa to Tigray, it could also be polluted by particulate matters emitted by vehicles and motors (Shilpa et al., 2011; Igbinosa et al., 2012). The main inflow river, Ancherkah, may also introduce agricultural runoff worsening the pollution. All these together may cause the deterioration of physico-chemical water quality parameters and accumulation of heavy metals in the lake.

To the best of our knowledge, assessment of the physico-chemical parameters and level of heavy metals in Lake Haiq has not been reported. Thus, the purpose of this study was to assess the level of selected heavy metals $(\mathrm{Pb}, \mathrm{Cd}, \mathrm{Cu}$, and $\mathrm{Zn})$ and physico-chemical parameters (temperature, $\mathrm{pH}$, turbidity, electrical conductivity (EC), total dissolved solid (TDS), total alkalinity (TA), chloride, ammonia, nitrate and sulphate) of Lake Haiq, Ethiopia.

While standard methods (GOI and GON, 1999) were used for the analysis of the physico-chemical parameters, Inductively Coupled Plasma-Optical Emission Spectrometry (ICP-OES), which is the most powerful with high selectivity, sensitivity, precision, and accuracy (Boevski and Daskalove, 2007) was used for the determination of the studied heavy metals.

\section{EXPERIMENTAL}

\section{Description of the study area}

The study was conducted in Lake Haiq, which is one of the highland lakes of Ethiopia located in Northern part of Ethiopia, Amhara Regional State, South Wollo Administrative Zone (Figure 1), at $11^{\circ} 15^{\prime} \mathrm{N}$ latitude, $39^{\circ} 57^{\prime} \mathrm{E}$ longitude, and at an altitude of 2,030 m above sea level (Betel Assefa, 2010). It is a crater lake with surface area, maximum depth and mean depth of $23.2 \mathrm{~km}^{2}, 88 \mathrm{~m}$ and $37.4 \mathrm{~m}$, respectively (Betel Assefa, 2010). The only stream of any size entering the lake is the Ankarka River, which flows to its south east corner. The lake has no visible outlet. A small town called Haiq is located at the southern shore of the lake. The water level of the lake fluctuates with variability of rainfall, its maximum volume being during the rainy season. The area is characterized by a sub-humid tropical climate with an average annual rainfall of $1211.4 \mathrm{~mm}$ and a mean annual temperature of around $25.9{ }^{\circ} \mathrm{C}$ (Betel Assefa, 2010).

\section{Selection of sampling sites and description}

Six sampling sites; labeled as site-1 to site-6 (Figure 1) covering the whole area of the lake were selected and the water samples were collected just from the surface of the lake.

Sampling site -1 is located along Haiq Estifanos Monastery, which serves as holy site for Orthodox Christian pilgrims. Wastes released from habitats and cattle watering at the site may influence the quality of the lake. This site which is also close to the highway may receive particulate pollutants related to motor vehicles.

Sampling site-2 is situated to the opposite of Haiq Estifanos Monastery. It is the site of minimally impacted physical habitat, low human population pressure and 


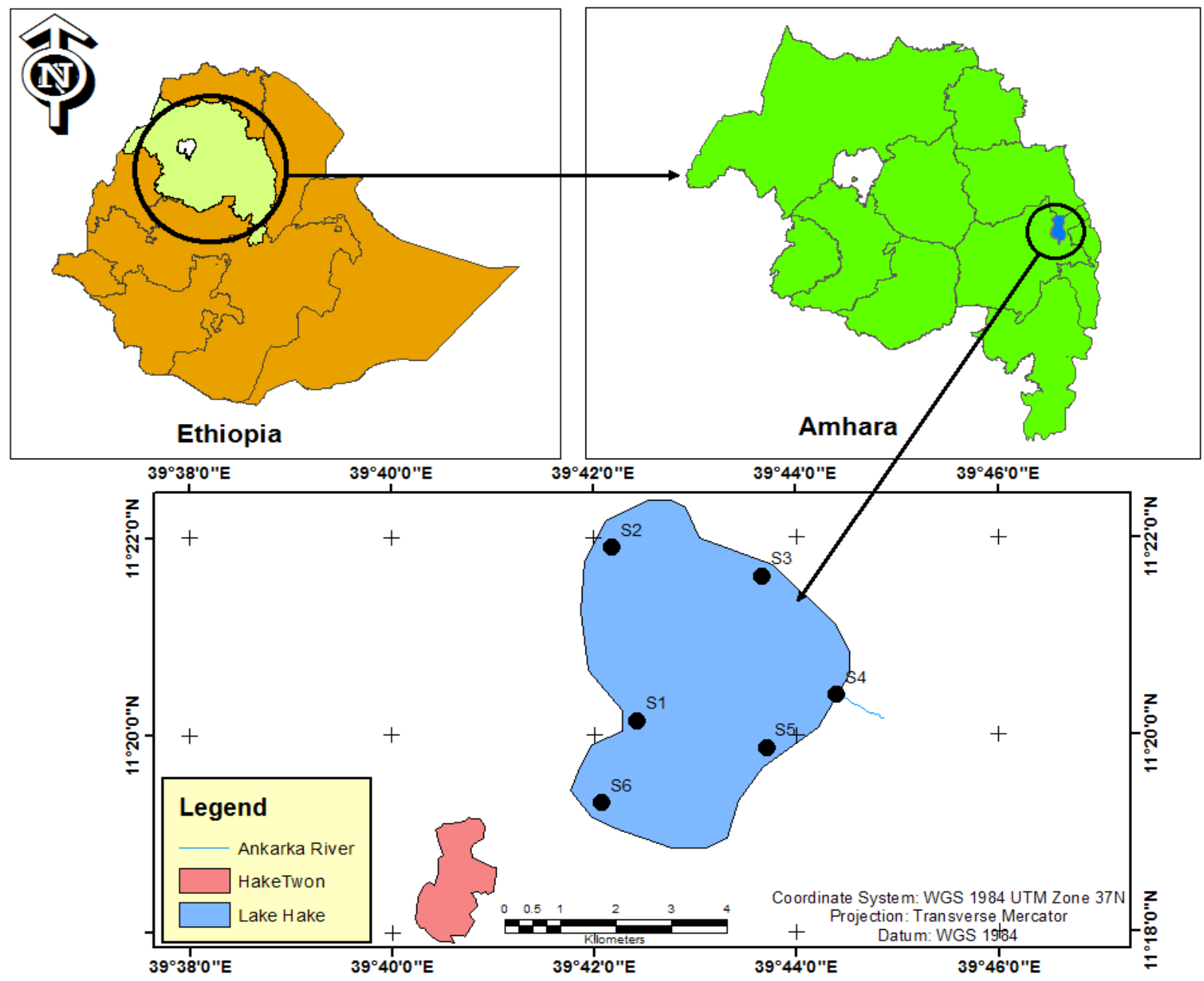

Figure 1. The map of the study area with sampling sites marked as S1through S6.

no known discharge and hence used as reference site. Sampling site-3 is the site along which the lake is used by the community for irrigation, fetching water for drinking, bathing, washing clothes, cattle drinking etc.

Sampling Site-4 is near the entry of the Ankarka River. This river loaded with industrial waste and dust materials may have the chance of altering the quality of the lake water.

Sampling site-5 is located on the side of the Logo of Haiq Logi recreation. This site does not have point source of pollution but there may be non-point source of pollution from the agricultural land and soil of the area.

Sampling site-6 is located near the Haiq town and is commonly used for recreational purpose. Since there is population pressure along this site, it was found congested with non-biodegradable use throw plastic wastes. This site is the area where the lake receives effluent of the Hotels as well as urban runoff.

\section{Instruments and apparatus}

pH meter (Wagtech pH meter, W-30200), turbidity meter (HACH2100AN), electrical conductivity (Wagtech EC/TDS meter, W-30210), Photometer (Wagtech 500, palintest Ltd, England), refrigerator (FR 1082), digital electrical balance (PW 124), Ice box (Lec technical), Global positioning system (GPS) (Garmin 12 Channel GPS, USA), and Inductively Coupled Plasma-Optical Emission Spectrometry (ICP-OES) (ULTIMA 2, HORIBA scientific) were used in this study. 


\section{Chemicals and Reagents}

$\mathrm{HNO}_{3}$ (69-72\%), and $\mathrm{HCl}$ (35-38\%) (both from Fisher Scientific, UK), $\mathrm{AgNO}_{3}, \mathrm{~Pb}\left(\mathrm{NO}_{3}\right)_{2}, \mathrm{Cd}\left(\mathrm{NO}_{3}\right)_{2} 4 \mathrm{H}_{2} \mathrm{O}$, $\mathrm{Cu}\left(\mathrm{NO}_{3}\right)_{2} \cdot 3 \mathrm{H}_{2} \mathrm{O}$, and $\mathrm{Zn}\left(\mathrm{NO}_{3}\right)_{2} \cdot 6 \mathrm{H}_{2} \mathrm{O}$ (all from Blulux Laboratories Ltd,) were used. All chemicals and reagents used were of analytical grade and were used without further purification. Freshly prepared distilled water and deionized water were used throughout the experiment for preparing standard solutions, dilution and rinsing apparatus.

\section{Procedures}

\section{Sample collection and preservation}

Water samples were collected from the surface of the lake in April, 2014 just before noon. The samples were collected from the six sampling sites illustrated under sampling site description using one liter-capacity cleaned polyethylene bottles. A composite water sample was obtained from each sampling site by mixing the grab samples collected from four spots of the same depth (surface) at each sampling site. Hence, water samples from the six sampling sites were collected separately, and preserved in ice box to minimize physico-chemical changes.

Each one L composite water sample collected from each sampling site was then divided into two equal portions; a portion for the physico-chemical analysis and the other for the analysis of dissolved heavy metals. One portion was first filtered using Whatman No 1filter paper in to a $500 \mathrm{~mL}$ pre-cleaned polyethylene bottle, and acidified by adding two $\mathrm{mL}$ of concentrated $\mathrm{HNO}_{3}$ to minimize precipitation and adsorption on the container walls (APHA, 1998) and was then stored in a refrigerator until analysis. The other portion of the water sample was used for the determination of physico-chemical parameters without any pre-treatment.

\section{Analysis of physico-chemical parameters}

Temperature, $\mathrm{pH}$, turbidity, electrical conductivity (EC) and total dissolved solids (TDS) were measured in the field (in situ). Temperature readings were made on site by directly immersing the probe in to the surface water. The $\mathrm{pH}$ of water samples were measured at each sampling site by inserting the $\mathrm{pH}$ meter probe (calibrated using $\mathrm{pH} 4.00,7.00$, and 10.00 standard buffer solutions prior to measurement) in to the water immediately after collection. Turbidity, EC and TDS readings were also taken at the same time as $\mathrm{pH}$.

Total alkalinity (TA) was determined by a standard method (titration) using $0.1 \mathrm{~N} \mathrm{HCl}$ as a titrant, and methyl-orange and phenolphthalein as endpoint indicators. Similarly, chloride was determined by titration using silver nitrate as titrant, and potassium chromate $\left(\mathrm{K}_{2} \mathrm{CrO}_{4}\right)$ solution as an indicator following a standard analytical procedure for water analysis (GOI and GON, 1999). Ammonia, nitrate and sulphate were determined using palintest photometer following standard procedures (Osei and Jackson, 2008).

\section{Heavy metal analysis}

To prepare stock solutions of $\mathrm{Pb}, \mathrm{Cd}, \mathrm{Cu}$, and $\mathrm{Zn}$ each of $1000 \mathrm{mg} / \mathrm{L}$ concentration, an appropriate amounts of $\mathrm{Pb}\left(\mathrm{NO}_{3}\right)_{2}, \mathrm{Cd}\left(\mathrm{NO}_{3}\right)_{2} \cdot 4 \mathrm{H}_{2} \mathrm{O}, \mathrm{Cu}\left(\mathrm{NO}_{3}\right)_{2} \cdot 3 \mathrm{H}_{2} \mathrm{O}$, and $\mathrm{Zn}\left(\mathrm{NO}_{3}\right)_{2} \cdot 6 \mathrm{H}_{2} \mathrm{O}$, respectively were taken. For each metal, the required amount of the corresponding salt was put in to a $1000 \mathrm{~mL}$ volumetric flask to which a $4 \mathrm{~mL}(1: 1) \mathrm{HNO}_{3}$ was added. After shaking, the solution, it was then diluted up to the mark with deionized water. Intermediate standard solutions of $10 \mathrm{mg} / \mathrm{L}$ concentration were prepared from the respective stock solution by dilution from which, standard working solutions of series concentrations were freshly prepared (Table 3). Following the analysis of the series concentrations for each metal, reagent blank and water samples were aspirated in to the ICP-OES where triplicate measurements for each were made. The ICP-OES operating conditions and emission wave length for each studied metal are shown in Table 1. 
Table 1. ICP-OES operational parameters and emission wave length of the studied heavy metals

\begin{tabular}{ll}
\hline Operational parameter & Value \\
\hline Plasma power (RF) & $1450 \mathrm{w}$ \\
Plasma gas (Ar) flow & $15 \mathrm{~L} / \mathrm{min}$ \\
Auxiliary Ar flow & $0.5 \mathrm{~L} / \mathrm{min}$ \\
nebulizer flow rate & $0.51 \mathrm{~L} / \mathrm{min}$ \\
Nebulizer pressure & $1.77 \mathrm{bar}$ \\
Pump speed & $20 \mathrm{rpm}$ \\
Sheath flow & $0.2 \mathrm{~L} / \mathrm{min}$ \\
\hline Studied metal & Emission wave \\
\hline $\mathrm{Pb}$ & 1 length (nm) \\
$\mathrm{Cd}$ & 220.4 \\
$\mathrm{Cu}$ & 226.5 \\
$\mathrm{Zn}$ & 327.4 \\
\hline
\end{tabular}

\section{Statistical Analysis of data}

To check whether the mean values of the investigated parameters between sampling sites are significantly different or not, statistical analysis of data (one way ANOVA) using SPSS version 20 software was employed. Difference in mean values were accepted as being statistically significant if $\mathrm{p}<0.05$.

\section{RESULTS AND DISSCUSION}

\section{Physico-chemical analysis}

The average results for the investigated physico-chemical parameters are summarized in Table 2. As shown in the table, the temperature of the lake varied between $22.84 \pm 1.47$ to $29.25 \pm 0.89{ }^{\circ} \mathrm{C}$ with a mean value of $26.46 \pm 2.34{ }^{\circ} \mathrm{C}$. The variation may be ascribed to the sampling time temperature difference at the sampling sites.
The $\mathrm{pH}$ value of the surface water of Lake Haiq ranged from $8.71 \pm 0.13$ to $8.90 \pm 0.08$, the mean value being $8.83 \pm 0.07$. The $\mathrm{pH}$ value showed slight alkalinity compared to the allowed WHO guideline value (Table 2). The temperature and $\mathrm{pH}$ variation showed the same trend through the sampling sites (Figure 2).

While turbidity is a measure of cloudiness of water, high turbidity may indicate the presence of organisms including bacteria, viruses, and parasites that can cause symptoms such as nausea, cramps, diarrhea, and associated headaches (Akoto and Adiyiah, 2007). In the present investigation, sampling sites S3, S5, and S6 showed higher turbidity values than the recommended limit by WHO standard, which may be due to contamination of the water by wastewater, garbage, mass bathing, offering foods, flowers, garlands and other religious matters.

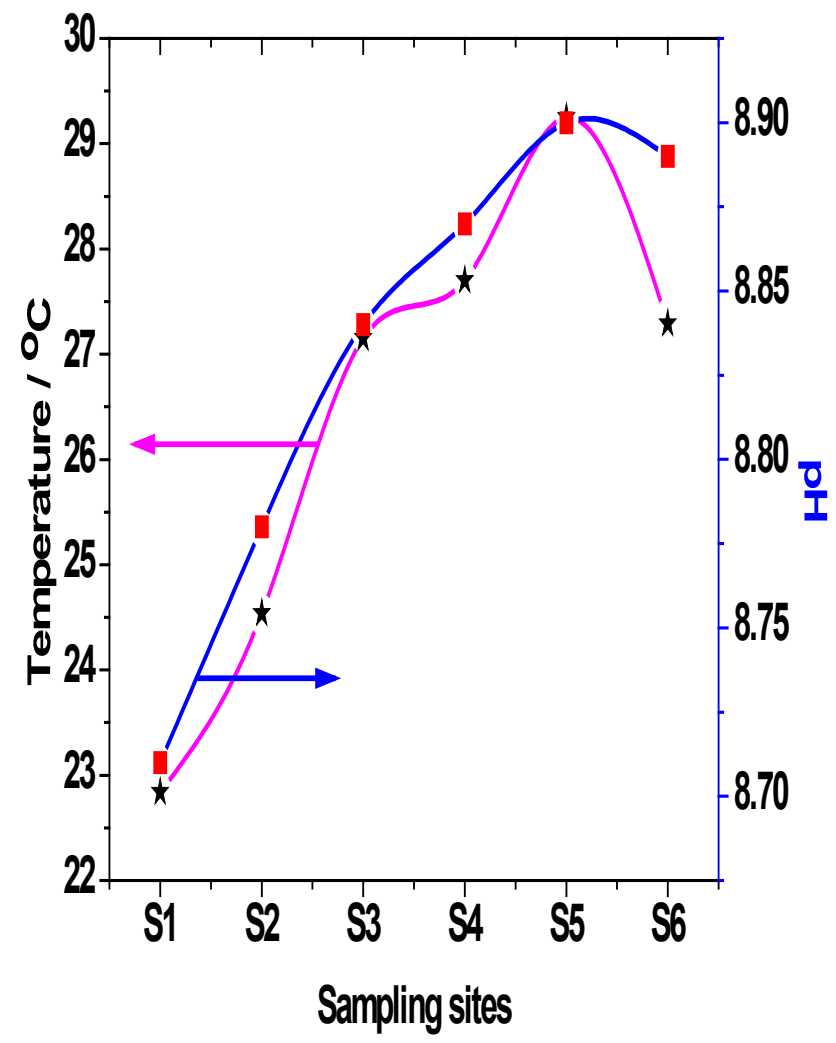

Figure 2. Trends of Temperature and $\mathrm{pH}$ with sampling sites. 


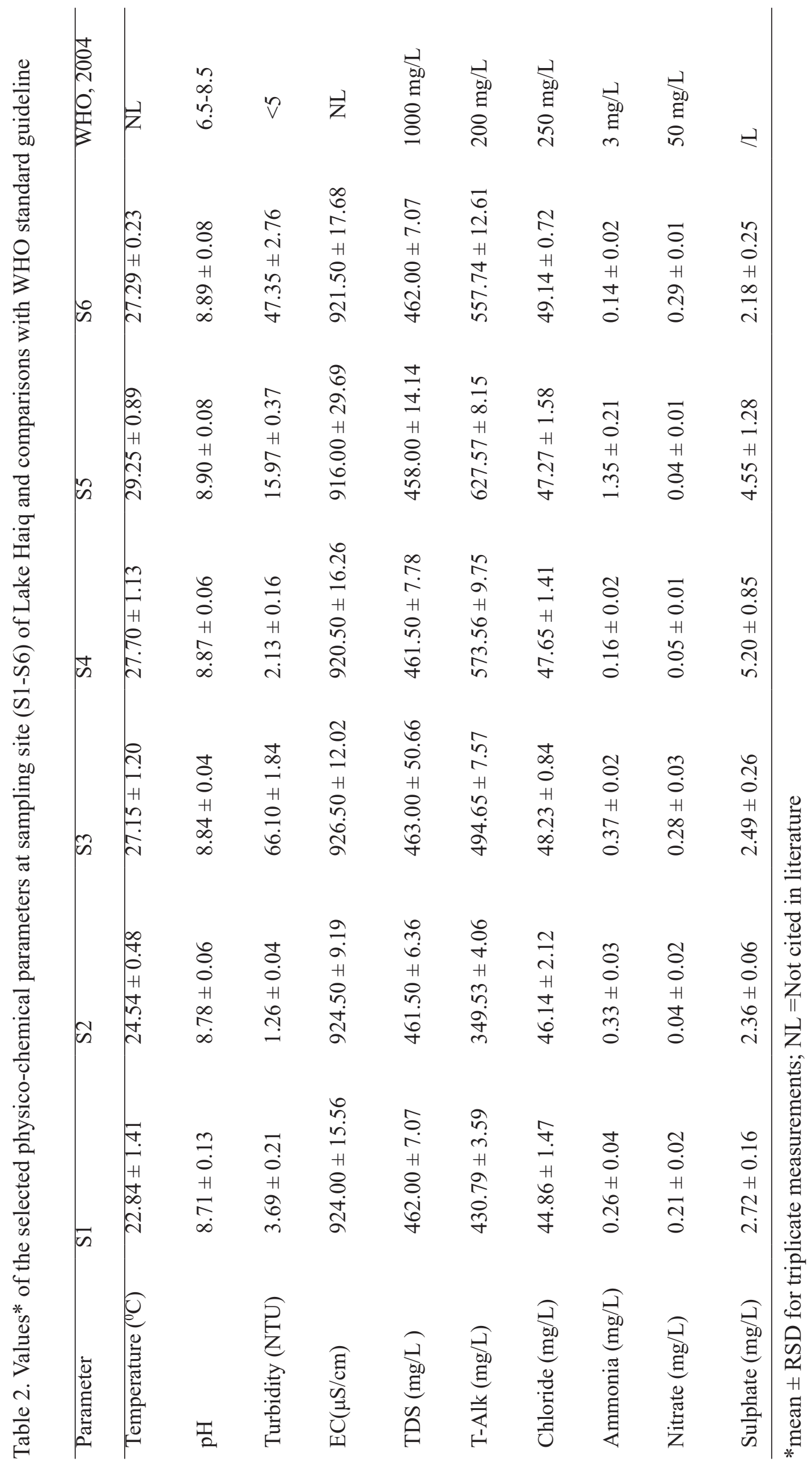


Electrical conductivity (EC) is an estimate of total dissolved salts in water. EC values between 2,500 and $10,000 \mu \mathrm{S} \mathrm{cm}^{-1}$ is not recommended for human consumption and normally not suitable for irrigation except for very salt tolerant crops with special management techniques (Yenkie et al., 2010). The electrical conductivity of the water sample collected from Lake Haiq varied between $916.00 \pm 29.69$ and 926.50 $\pm 12.02 \mu \mathrm{S} / \mathrm{cm}$, the highest value being for the water sampled at S3 which may be attributed to the geology along agricultural land and discharges of domestic effluents.

Total dissolved solids (TDS) is an important indicator of the suitability of water for drinking, recreational, irrigation and industrial use. TDS includes those materials dissolved in the water including bicarbonate, sulphate, phosphate, nitrate, calcium, magnesium, sodium, organic ions, and other ions which are important in sustaining the aquatic life (Zenebe Yirgu, 2011). As can be observed from Table 2, the TDS values ranged from $458.00 \pm 14.14$ to $463.00 \pm$ $5.66 \mathrm{mg} / \mathrm{L}$ indicating TDS throughout the lake is under WHO's maximum allowable concentration $(1,000$ $\mathrm{mg} / \mathrm{L})$.

Alkalinity is an estimate of the ability of water to resist change in $\mathrm{pH}$ upon addition of acids. The various ionic species that contribute to alkalinity include bicarbonate, hydroxide, phosphate, borate and organic acids (Yadaw et al., 2012). Total alkalinity values for the investigated samples were found to be in the range $349.53 \pm 4.06$ to $627.57 \pm 8.15 \mathrm{mg} / \mathrm{L}$ (Table 2 ). The total alkalinity of water collected from most of the sampling sites was higher than the permitted value by WHO guidelines $(200 \mathrm{mg} / \mathrm{L})$ which could be ascribed to higher carbon dioxide concentration and release of bicarbonates by sediments.

Higher level of chloride in natural water is a definite indication of domestic sewage. The ecological significance lies in its potential to regulate salinity of water and exert consequent osmotic stress on biotic communities (Shinde et al., 2011). In the present analysis, chloride concentration in the water samples was found in the range $44.86 \pm 1.47$ to $49.14 \pm 0.72 \mathrm{mg} / \mathrm{L}$ showing that all the values are under the maximum allowed concentration by WHO guidelines .Relative to the other sampling sites, higher chloride concentration at S6 (Table 2) could be due to large discharges of domestic sewage near the sampling site.

In the present investigation, the level of $\mathrm{NH}_{3}$ in all sampling sites ranged from $0.14 \pm 0.02$ to $1.35 \pm 0.21$ $\mathrm{mg} / \mathrm{L}$ which still is within the recommended level of ammonia in drinking water by the WHO $(3 \mathrm{mg} / \mathrm{L})$. Higher ammonia concentration at S5 (Table 2) might be due to fertilizer runoff and sewage releases into the Lake water.

The average nitrate concentration in the water samples collected from Lake Haiq ranged from 0.04 \pm 0.01 to $0.29 \pm 0.01 \mathrm{mg} / \mathrm{L}$ indicating the level is still under the permissible limit of WHO. Low nitrate level is an indication of the absence of nitrogen fixing bacteria responsible for convertion of ammonia in to nitrate. The relatively higher nitrate concentration at sampling site S6 (Table 2) might be due to the use of Nitrogen fertilizers in the agricultural fields along the shore and effluents discharged from domestic wastes.

Sulphate occurs naturally in water as a result of leaching from gypsum and other common minerals. Discharge of industrial wastes and domestic sewage tend to increase its concentration (Gopalkrushna, 2011). In the present investigation, the levels of Sulphate $\left(\mathrm{SO}_{4}{ }^{2-}\right)$ in the Lake ranged from $2.18 \pm 0.25$ to $5.20 \pm 0.85 \mathrm{mg} / \mathrm{L}$ all of which being much lower than the WHO recommended value. A relatively higher $\mathrm{SO}_{4}^{2-}$ level at sampling site $\mathrm{S} 4$ (Table 2) might be due to geological origin through weathering of sulfur containing rocks.

\section{Heavy metal analysis}

\section{Calibration curve and method Detection Limit}

Five working standard solutions for each analyzed metal were prepared freshly from the respective intermediate standard solution as discussed under the experimental section. Table 3 presents the list of 
Table 3. Summary of the working standard concentrations, linear regression equation, correlation coefficient and method LOD for each studied heavy metals using ICP-OES method

\begin{tabular}{lllll}
\hline Metal & $\begin{array}{c}\text { Conc. of standard solutions } \\
(\mathrm{mg} / \mathrm{L})\end{array}$ & Linear regression equation & $\mathrm{R}^{2}$ & $\begin{array}{c}\text { LOD } \\
(\mathrm{mg} / \mathrm{L})\end{array}$ \\
\hline $\mathrm{Pb}$ & $0.05,0.1,0.2,0.4,0.8$ & $\mathrm{I}=173,468.79+6,114.305 \mathrm{C}$ & 0.99967 & 0.0039 \\
$\mathrm{Cd}$ & $0.005,0.01,0.02,0.04,0.08$ & $\mathrm{I}=278440.53+242,449.18 \mathrm{C}$ & 0.99565 & 0.00073 \\
$\mathrm{Cu}$ & $0.25,0.5,1,2,4$ & $\mathrm{I}=1,045,430+5,072.66 \mathrm{C}$ & 0.99483 & 0.00051 \\
$\mathrm{Zn}$ & $0.25,0.5,1,2,4$ & $\mathrm{I}=30,518.65+384,109.72 \mathrm{C}$ & 0.99992 & 0.0012
\end{tabular}
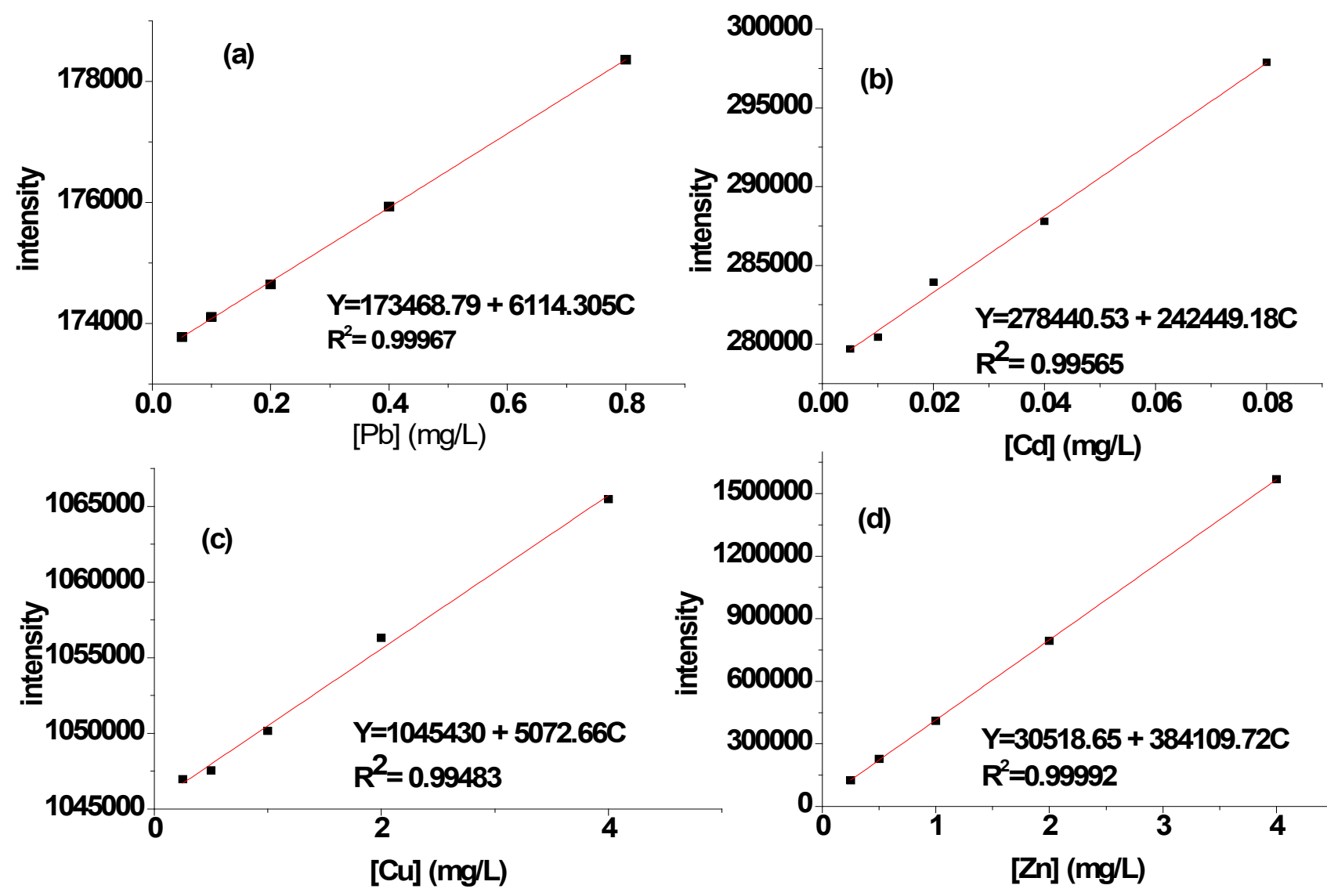

(d)

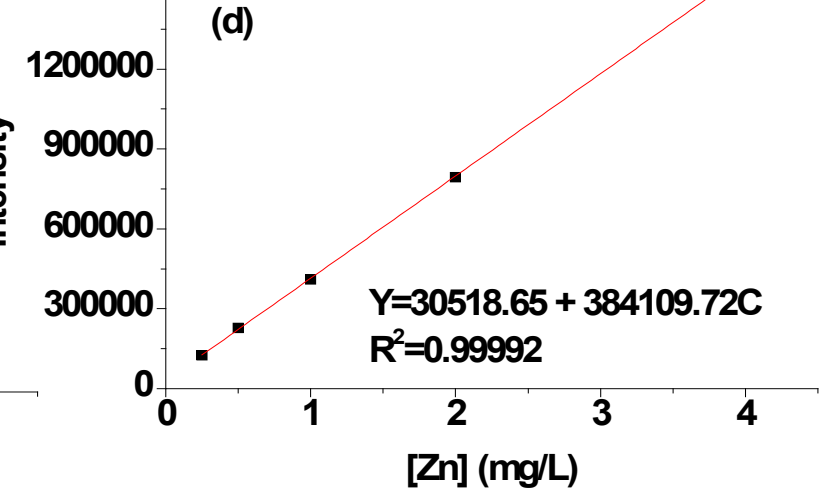

Figure 3. ICP-OES calibration curves for (a) $\mathrm{Pb}$, (b) $\mathrm{Cd}$, (c) $\mathrm{Cu}$ and (d) $\mathrm{Zn}$ standards of different

working standard solutions, corresponding regression equation, correlation coefficient and calculated LOD ( $\mathrm{s}=3 \sigma$ for $\mathrm{n}=3$ ) (Peter and Kirk, 2002) for each analyzed metal.
ICP-OES determination of the concentration of heavy metals in water samples

ICP-OES was used for the determination of the level of the studied heavy metals in the water samples collected from Lake Haiq. After measuring the ICP- 
Table 4. Level of the studied heavy metals in Lake Haiq by sampling site

\begin{tabular}{|c|c|c|c|c|}
\hline \multirow[t]{2}{*}{ Sampling site } & \multicolumn{4}{|c|}{ Metal concentration* in $\mathrm{mg} / \mathrm{L}$} \\
\hline & $\mathrm{Pb}$ & $\mathrm{Cd}$ & $\mathrm{Cu}$ & $\mathrm{Zn}$ \\
\hline S1 & $0.093 \pm 0.004$ & BDL & $0.540 \pm 0.320$ & $0.160 \pm 0.002$ \\
\hline S2 & $0.064 \pm 0.008$ & BDL & $0.260 \pm 0.072$ & $0.160 \pm 0.001$ \\
\hline S3 & $0.082 \pm 0.015$ & BDL & $0.360 \pm 0.140$ & $0.150 \pm 0.003$ \\
\hline S4 & $0.069 \pm 0.007$ & BDL & $0.450 \pm 0.109$ & $0.160 \pm 0.001$ \\
\hline S5 & $0.097 \pm 0.006$ & BDL & $1.940 \pm 0.398$ & $0.160 \pm 0.001$ \\
\hline S6 & $0.108 \pm 0.001$ & BDL & $1.440 \pm 0.120$ & $0.150 \pm 0.002$ \\
\hline Allowed limit** & 0.01 & 0.003 & 2 & 3 \\
\hline
\end{tabular}

$*$ mean \pm RSD for $\mathrm{n}=3 ; \mathrm{BDL}=$ below instrument detection limit, $* *=\mathrm{WHO}(2004)$

OES signal for each metal in the collected samples, the corresponding concentrations were calculated by inserting the signals in to the respective regression equation. Table 4 presents the summary of the levels of the studied heavy metals in the. As can be seen from the table, cadmium concentration was below the method detection limit while the rest were above the respective method detection limits.

The levels of $\mathrm{Cu}$ and $\mathrm{Zn}$ were found to be under the respective allowed levels by WHO guidelines showing that there is no risk of pollution due to these metals. On the contrary, $\mathrm{Pb}$ which has been found to be responsible for quite a number of ailments in humans such as chronic neurological disorders especially in fetuses and children was found at a level higher than the permitted level by WHO guidelines. The concen- tration of lead at all the sampling sites was found to be six to ten times higher than the permitted level by the WHO guidelines. As presented by Ogbonna et al. (2011), automobile exhaust fumes have been reported to account for about $50 \%$ of the total inorganic $\mathrm{Pb}$ absorbed by human beings. Other inputs of $\mathrm{Pb}$ into the environment are from used dry-cell batteries, from sewage effluent, runoff of wastes and atmospheric deposition. In this regard, the highest value of lead detected at sampling site S6 could partly be accounted for the closeness of the site to the high way (Addis Ababa-Tigray) from where vehicle emission may pollute the water system and partly for the garage located near the site from where lead from car batteries could leak in to the water system.

Table 5. Comparison of the level of $\mathrm{Pb}$ detected in the water of Lake Haiq (mg/L) against its level in reported works.

\begin{tabular}{llll}
\hline Name of the Lake & Country & $\mathrm{Pb}$ & Reference \\
\hline $\begin{array}{l}\text { Mahrulu } \\
\text { Muhazi }\end{array}$ & Iran & 0.0050 & Moore et al. (2009) \\
Baringo & Rwanda & 0.2920 & Nhapia et al. (2012) \\
Manzala & Kenya & 0.0430 & Ochieng et al. (2007) \\
Hawassa & Egypt & 0.0990 & Saeed and Shaker (2008) \\
Koka & Ethiopia & 0.0030 & Zenebe Yirgu (2011) \\
Haiq & Ethiopia & 0.0006 & Larissa et al. (2012) \\
\hline
\end{tabular}


Comparison of the level of $\mathrm{Pb}$ in the studied Lake with its values in Lakes of reported works is presented in Table 5. As shown in the table, the level of $\mathrm{Pb}$ in Lake Haiq was higher than its value in the two Ethiopian Lakes (Hawassa and Koka). Moreover, it was higher than its values in Lakes Baringo (Kenya) and Mahrulu (Iran), but lower than (ahazi (Rwanda) and Manzala (Egypt) lakes.

\section{One way ANOVA analysis}

As described under the experimental section, the p-values for all the studied parameters were calculated using the SPSS version 20 software. According to the result, the calculated values of temperature $(p=$ $0.006)$, turbidity $(\mathrm{p}=0.000), \mathrm{TA}(\mathrm{p}=0.000), \mathrm{NH}_{3}(\mathrm{p}$ $=0.00), \mathrm{NO}_{3}{ }^{-}(\mathrm{p}=0.00), \mathrm{SO}_{4}{ }^{2-}(\mathrm{p}=0.013), \mathrm{Pb}(\mathrm{p}=$ $0.000)$, and $\mathrm{Cu}(\mathrm{p}=0.000)$ at different sampling sites showed statistically significant difference and hence a pooled mean cannot be used as a representative of the values of each parameter at the six sampling sites. The significant variation among sampling sites could be due to the difference in sampling time, anthropogenic influences and geographical location.

In contrast, the difference between the results obtained at the six sampling sites for $\mathrm{pH}(\mathrm{p}=0.409), \mathrm{EC}$ $(\mathrm{p}=0.992)$, TDS $(\mathrm{p}=0.993), \mathrm{Cl}^{-}(\mathrm{p}=0.176)$, and $\mathrm{Zn}$ $(p=0.704)$ were not statistically significantly different. In such a case, a pooled mean can be used as a representative value of the studied parameter for its values at the six sampling sites.

\section{CONCULUSION}

This study revealed that EC, TDS, chloride, ammonia, nitrate, and sulphate in Lake Haiq were within the WHO recommended limit whereas $\mathrm{pH}$, turbidity and TA were above the recommended limit. One way ANOVA analysis showed that results for some studied parameters differ significantly among sampling sites, which might be ascribed to the different sources of pollution and sampling time. Among the studied heavy metals, $\mathrm{Pb}, \mathrm{Cu}$ and $\mathrm{Zn}$ were detected in all sampling sites while $\mathrm{Cd}$ was not detected at any sam- pling site. Amongst the assessed heavy metals, lead was found to be in a level above the WHO recommended limit for drinking water. The potential cause for high level of $\mathrm{Pb}$ in the lake water may be the intense emission by vehicles along the nearby highway (Addis Ababa to Tigray) and discharges from the garage around the lake.

Hence, the presence of heavy metals in a detectable amounts in a water system used for fishing appended on the bio-accumulating property of the metals obviously leads to the entrance of the metals in to the food chain. Periodical monitoring of the lake water quality is thus required to assess the level of the heavy metals and physico-chemical parameters. Since leather factory is present around the lake, the level of chromium in the lake should also be investigated before it causes health problems on the bio-system.

\section{REFERENCES}

Akoto, O and Adiyiah, J. (2007). Chemical analysis of drinking water from some communities in the brong ahafo region. International Journal of Environmental Science and Technology 4(2): 211-214.

APHA (1998). American Public Health Association, Standard Methods for the Examination of Water and Wastewater, 20th ed., Washington D.C.

Arian M.B., T.G. Kazi, M.K. Jamali, H.I. Afridi, J.A. Baig, Jablini, N and Shah, A.Q. (2008). Evaluation of physico-chemical parameters of Manchar Lake water and their comparison with other global published values. Pakistan Journal of Analytical and Environmental; Chemistry 9(2):101-109.

Arumugam, G., Elizabeth, S.H., Thirumagal, J., Islam, N.N and Panneerselvam, A. (2013). Evaluation of water quality of Pulliy Yakanu Lake with reference to physico-chemical aspects at Vellore District. World Journal of Pharmacy and Pharmaceutical Sciences 2(5): 3641-3649.

Benzer, S., Arslan, N and Y1lmaz, M. (2013). 
Concentrations of metals in water, sediment and tissues of Cyprinus carpio from Mogan Lake (Turkey). Iranian Journal of Fisheries Sciences 12(1): 45-55.

Betel Assefa. (2010). Studies on Benthic Macroinvertebrates of Lake Haiq, Ethiopia. M.Sc. Thesis, Addis Ababa University, Ethiopia.

Boevski, I and Daskalova, N. (2007). Determination of toxic and heavy metals in surface river water samples using Inductively coupled plasma Atomic Emission spectrometry (ICP-AES). Journal of the University of Chemical Technology and Metallurgy 42(4): 419-426.

Government of India (GOI) and Government of The Netherland (GON). (1999). Technical Assistance hydrology project. Standard Analytical Procedures for Water Analysis.

Gopalkrushna, M. (2011). Determination of PhysicoChemical parameters of Surface Water Samples in and around Akot City. International Journal of Research in Chemistry and Environment 1(2): 183187.

Igbinosa, E.O., Odjadjare E.E., Ajuzie, C.U and Adewole, E.M. (2012). Assessment of physicochemical qualities, heavy metal concentrations and bacterial pathogens in Shanomi Creek in the Niger Delta, Nigeria. African Journal of Environmental Science and Technology 6(11): 419-424.

Larissa, D., Mesfin, M and Elias, D. (2013). Assessment of heavy metals in water samples and tissues of edible fish species from Hawassa and Koka Rift Valley lakes, Ethiopian Environment Monitoring and Assessment 185(4): 3117-3131.

Moore, F., Orghani, G and Qishla, A. (2009). Assessment of Heavy metal contamination in water and surface sediments of the Maharlu saline Lake, Swiran. Iranian Journal of Science and Technology, Transaction A 33(1): 44-54.
Nhapia, I., Walib, U.G., Usanzinezab, D and Kashaigilic, N. (2012). Distribution of Heavy Metals in Lake Muhazi, Rwanda. The Open Environmental Engineering Journal 5: 96-102.

Ochieng, E,Z., Lalah, J.O and Wandiga, S.O. (2007). Analysis of Heavy metals in water and surface sediment in five Rift Valley lakes in Kenya for assessment of recent increase in anthropogenic activities. Bulletin of Environmental Contamination and Toxicology 79: 570-576.

Ogbonna, O., LJimoh, W., Awagu, E.F and Bamishaiye, E.I. (2011). Determination of some trace elements in water samples within kano metropolis. Advances in Applied Science Research 2(2): 62-68.

Osei, A and Jackson, A. (2008). Dissolved nitrogen in drinking water resources of farming communities in Ghana. African Journal of Environmental Science and Technology 2(2):031-035.

Patil, P.N., Sawant, D.V and Deshmukh, R.N. (2012). Physico-chemical parameters for testing of water A review. International Journal of Environmental Sciences 3(3): 1194-1207.

Peter, E.J and Kirk, C. (2002). Advances in the determination of inorganic ions in potable waters by ion chromatography. Journal of Environmental Monitoring 4(1): 10-15.

Saeed, S.M and Shaker, I.M. (2008). Assessment of heavy metals pollution in water and sediments and their effect on Oreochromis Niloticus in Northern Delta Lakes, Egypt. 8th International Symposium on Tilapia in Aquaculture.

Shilpa, P., Goroba, C.S., Suhas, J.A and Raut, P.D. (2011). Study of physico-chemical and biological characteristics of lakes from Shivaji University Campus, Kolhapur, Maharashtra. Advances in Applied Science Research 2(6): 505-519.

Shinde, S.E., Pathan, T.S and Raut, D.L. (2011). Sonawane, Studies on the Physico-chemical 
Parameters and Correlation Coefficient of Harsoolsavangi Dam, District Aurangabad. India. MiddleEast Journal of Scientific Research 8(3): 544-554.

Tolera, S. (2007). Determination of common ions and heavy metals in bottled mineral water consumed in Addis Ababa (Ethiopia). M.Sc. Thesis, Addis Ababa University, Ethiopia.

Verma, R and Dwivedi, P. (2013). Heavy metal water pollution- A case study. Recent Research in Science and Technology 5(5): 98-99.

WHO (1984). Guideline for Drinking Water Quality. Health Criteria and Supporting Information 2: 63315.

WHO (2004). Guidelines for drinking-water quality, 3rd ed. WHO, Geneva, Switzerland.

Yadaw, K.K., Kumer, V., Aryal, S and Singh, D. (2012). Physico-chemical analysis of selected ground water samples of Agra city, India. Recent Research in Science and Technology 4(11): 51-54.

Yenkie, M.K., Battalwar, D.G., Gandhare, N.V and Dhanorkar, D.B. (2010). A study and interpretation of physico-chemical characteristic of Lake water quality in Nagpurcity (India). Rasayan 3(4): 800810.

Zenebe Yifru. (2011). Accumulation of certain heavy metals in Nile Tilapia (Oreochromis niloticles) fish species relative to heavy metal concentrations in the water of Lake Hawassa. M.Sc. Thesis, Addis Ababa University, Ethiopia. 